International Journal of Occupational Safety and Ergonomics (JOSE), 2018

Vol. 24, No. 2, 181-189, https://doi.org/10.1080/10803548.2016.1216365

\title{
The protective effect of job satisfaction in health, happiness, well-being and self-esteem
}

\author{
Cibele Satuf, Samuel Monteiro*, Henrique Pereira, Graça Esgalhado, \\ Rosa Marina Afonso and Manuel Loureiro \\ University of Beira Interior, Portugal
}

\begin{abstract}
The purpose of this article is to analyze the possible effects of job satisfaction on mental and physical health, happiness, subjective well-being and self-esteem. A total of 971 Portuguese-speaking adults participated in this study. Most participants reported high rates of satisfaction with their colleagues, the nature of their work and leadership, while reporting dissatisfaction with regard to salaries and promotions. Results indicated the existence of the protector effect of job satisfaction for health, happiness, subjective well-being and self-esteem, in addition to reinforcing the importance of maintaining a positive evaluation of one's work. As a practical implication, the results may suggest that the effects of personnel management policies which emphasize job satisfaction could potentially lead to improvements in levels of health, happiness, subjective well-being and workers' self-esteem, all of which are factors that can potentially improve organizational performance. The study also considered its limitations and the possibility for future investigation.
\end{abstract}

Keywords: job satisfaction; health; happiness; subjective well-being; self-esteem

\section{Introduction}

Job satisfaction is one of the most relevant variables in the field of Organizational and Work Psychology. It attracts the attention of researchers who aim to contribute empirically to explain its constructs, as well as to understand what elements and variables act as its consequents and antecedents. Job satisfaction is also a focus of human resources managers seeking to develop internal strategies and policies regarding the promotion of workers. The literature suggests several consequences of job satisfaction both within and outside the organization of employment. Prior research also associates job satisfaction with an increase in affective commitment to the organization,[1,2] productivity,[3] organizational commitment,[4] and reduced absenteeism [5] and turnover.[6] Outside the organizational context there are indications that labor dissatisfaction can cause damage to one's physical [7] and mental [8] health, and can decrease one's well-being,[9] happiness [10] and selfesteem.[11,12]

While we have significant evidence for the impact of job satisfaction on maintaining health indices, happiness, well-being and self-esteem, there is also a need to highlight the effect of these variables on the organization of employment. A healthy, happy worker with high selfesteem contributes to the improvement of organizational results,[13] which can be reflected in a decrease of involuntary absenteeism [5] and an increase of productivity, competitiveness [14] and organizational effectiveness.[15]

\subsection{Job satisfaction}

Job satisfaction concerns the assessment of the work experience, through a process that references one's beliefs, values and goals related to work and that guides behavioral tendencies.[16] Locke,[17] one of the leading scholars of this construct, considers job satisfaction to be a pleasurable emotional state resulting from the evaluation that one has of their work and the realization that this evaluation allows concerning the satisfaction of important values.

The concept is multidimensional, as it involves both the overall assessment and the judgment of different factors related to work.[18] As highlighted by Tamayo,[19] these factors include: salary and benefits, colleagues, supervision, working conditions, job nature, career advancement, job stability, personal development and the amount of work. In a study by Cavalhieri,[20] job satisfaction is defined using the dimensions of salary, coworkers, promotions and working conditions. However, there is no consensus with respect to the size or assessed factors used to evaluate one's work; therefore, the most cited today are satisfaction with salary, coworkers, leadership, promotions and the nature of one's work itself.[21]

\subsection{Physical and mental health}

The World Health Organization's (WHO) 1948 Declaration defines health as 'a state of complete physical, mental, and social well-being, and not merely the absence of

*Corresponding author. Email: smonteiro@ubi.pt 
disease or infirmity.'[22,p.9] The WHO also recognized health as a resource for everyday life and as a positive concept, emphasizing personal resources and social and physical abilities. Initially health measurements were focused on the identification of disease or the absence of symptoms, and only in the second half of the 20th century did they focus on health, performance and functionality.[23]

We can distinguish between physical, mental and social health.[24] Physical health includes physical functioning, performance and the ability to perform a variety of basic operating activities common to a person in good physical condition. Mental health focuses on symptoms related to affective and mood disorders, anxiety disorders, positive well-being and self-control. Mental health also emphasizes the importance of psychological states, rather than the somatic or physiological manifestations of these states. Social health comprises the interactions and interpersonal activities that indicate social connections.[25]

\subsection{Happiness and well-being}

Well-being is a new concept and is often popularly regarded as being synonymous with happiness.[26] It underlies the hedonic conception of happiness, and refers to the pleasure and displeasure of experiences, which cause judgments regarding positive and negative elements in life.[27] Well-being is a broad phenomenon that includes emotional responses from an individual, as well as overall judgments about one's life satisfaction.[28]

According to Hills and Argyle,[29] happiness is a multidimensional construct comprising cognitive and emotional elements. To Veenhoven,[30] happiness can be understood as a synonym of satisfaction with one's life, in combination with the concept of subjective well-being proposed by Diener. However, the author does not see life satisfaction as a mere cognitive assessment, but instead views this concept as a global judgment of life based on two sources of measurement. The first source assesses the cognitive comparison with one's perceived standards of a good life (contentment), while the second encompasses affective information about how a person feels most of the time (hedonic affection).

\subsection{Self-esteem}

The concept of self-esteem was first covered by William James in 1890, who defined it as a positive selfconsideration obtained by people when they can consistently meet or exceed the important goals of their lives. In the Social Sciences field, self-esteem can be defined as an overall assessment, usually affective, of the merits, values and importance of oneself.[31] It is often thought of as the evaluative component of self-concept.[32] There are scholars who also adopt a dichotomous approach when evaluating self-esteem. This approach divides self-esteem into the categories of high self-esteem, which is defined as when a person feels that they have value, and low selfesteem, which is characterized as when a person believes that they have no value and, as a result, they suffer from self-pity and self-contempt.[33] According to Rosenberg, the author of one of the oldest and most widely used self-esteem evaluation scales, self-esteem is a positive or negative overall attitude towards oneself.[34]

In the last century self-esteem received significant attention from social researchers, who studied its relation with problems such as drug abuse, crime, unemployment and violence.[31] More recent studies, however, relate the concept to several other aspects, such as well-being, academic success and learning abilities.[35] More specifically, self-esteem in psychology has been the focus of increasing attention, because there are several studies that indicate its causal role in many important life outcomes, such as physical health, interpersonal relationships and psychopathology.[31,36] Self-esteem has also been examined with respect to workers' behaviors and attitudes.[37]

Studies point out that health, happiness and well-being have different levels of consequences in the labor market, influencing behaviors such as job performance, absences and turnover.[38] In many cases, these constructs tend to have significant and positive associations. This implies a reciprocal relationship, and signifies that the emotions, attitudes and behaviors experienced at work can influence one's life outside the workplace, and vice versa.[39] Some studies indicate that one's job satisfaction may even influence the health, happiness and well-being of other family members. [40] In addition, self-esteem can improve self-confidence and the ability to handle pressure and fatigue,[41] can influence job satisfaction levels and can affect the results achieved by workers.[42] It is noteworthy that a negative self-perception can negatively influence how workers assess their personal skills and abilities,[43] leading to a lack of appreciation of their own potential.

Faced with this evidence, it is important to understand that the effects of job satisfaction are not limited to workers' routines, but that they can impact the levels of productivity, quality, organizational competitiveness and profitability throughout the organization.[14] Thus, the main objective of this research is to assess the influence of job satisfaction on the levels of health, happiness, well-being and self-esteem among a sample of employed participants.

\section{Method}

\subsection{Sample and participants}

The sample consisted of 971 adult subjects. All subjects were Portuguese speakers, with a mean age of 40.73 (SD 11.95) years. Regarding the gender of the participants, the sample was relatively balanced. With regard to marital status, a plurality of sample members was married (44\%). The vast majority of participants possessed a 
Table 1. Sociodemographic characteristics $(N=971)$.

\begin{tabular}{|c|c|c|}
\hline Variable & $N$ & $\%$ \\
\hline \multicolumn{3}{|l|}{ Gender } \\
\hline Male & 452 & 46.6 \\
\hline Female & 517 & 53.2 \\
\hline \multicolumn{3}{|l|}{ Marital status } \\
\hline Single & 270 & 27.9 \\
\hline Married & 426 & 44.0 \\
\hline Civil union & 100 & 10.3 \\
\hline Widowed & 10 & 1.0 \\
\hline Emotional commitment & 72 & 7.4 \\
\hline Divorced/separated & 91 & 9.4 \\
\hline \multicolumn{3}{|l|}{ Children } \\
\hline Yes & 509 & 52.6 \\
\hline No & 458 & 47.4 \\
\hline \multicolumn{3}{|l|}{ Education } \\
\hline$<4$ years of school & 1 & 0.1 \\
\hline$\leq 6$ years of school & 2 & 0.2 \\
\hline$\leq 9$ years of school & 15 & 1.6 \\
\hline$\leq 12$ years of school & 98 & 10.2 \\
\hline Bachelor's & 287 & 29.7 \\
\hline Master's & 397 & 41.1 \\
\hline $\mathrm{PhD}$ & 165 & 17.1 \\
\hline \multicolumn{3}{|l|}{ Occupational status } \\
\hline Student worker & 159 & 16.4 \\
\hline Works for others & 611 & 62.9 \\
\hline Self-employed & 166 & 17.1 \\
\hline Retired worker & 35 & 3.6 \\
\hline \multicolumn{3}{|l|}{ Professional category } \\
\hline Academic area & 214 & 22.0 \\
\hline Business person & 12 & 1.2 \\
\hline Management positions & 57 & 5.9 \\
\hline Mid-level positions & 191 & 19.7 \\
\hline Military field & 11 & 1.1 \\
\hline Operational level positions & 39 & 4.0 \\
\hline Top-level positions & 400 & 41.2 \\
\hline Other & 4 & 0.4 \\
\hline \multicolumn{3}{|l|}{ Nature of work institution } \\
\hline Public & 423 & 45.8 \\
\hline Private & 468 & 50.6 \\
\hline Other & 33 & 3.6 \\
\hline \multicolumn{3}{|l|}{ Type of activity } \\
\hline Industry & 107 & 11.8 \\
\hline Services & 772 & 84.9 \\
\hline Other & 30 & 3.3 \\
\hline \multicolumn{3}{|c|}{ Income sufficient to cover daily expenses } \\
\hline Yes & 569 & 59.3 \\
\hline No & 390 & 40.7 \\
\hline
\end{tabular}

university education (87.9\%), with $29.74 \%$ holding a bachelor's degree, $41.1 \%$ having a master's degree and $17.1 \%$ possessing a PhD. Furthermore, the majority of study participants works for others (62.9\%), acting mostly in toplevel positions $(41.2 \%)$ such as psychologists, doctors or lawyers. Most workers (59.3\%) assessed their income as sufficient for daily expenses and worked in the service sector $(84.9 \%)$. The distribution among professionals working in public and private companies was approximately balanced. Table 1 presents the participants' demographics based upon their responses.

\subsection{Procedures}

The request to participate in the sample was sent over the Internet between October 2014 and February 2015, through the use of email lists, contact with companies and social networks. The collection of online data has become quite common in the field of Psychology and Social Sciences, mainly due to lower printing costs, flexibility and anonymity in responses compared with the use of printed questionnaires.[44] Studies suggest that the results from online surveys maintain statistical equivalence compared with more traditional forms of data collection.[45] The form contained information about the objectives of the study in addition to presenting the research team involved, and included the terms of informed consent. Participants were guaranteed anonymity and confidentiality. The study met the ethical principles and guidelines for research with human beings proposed by the American Psychological Association.

\subsection{Measures}

We used a sociodemographic questionnaire that included items such as age, gender, marital status, education, employment status, nature of the organization of employment and an evaluation of one's salary.

Job satisfaction was measured using the short version of the Satisfaction at Work Scale, developed by Siqueira in 1995.[46] The scale has 15 items and assesses employee satisfaction dimensions, such as the nature of work, colleagues, boss/management interaction, promotions and salary. The short version of the Satisfaction at Work Scale utilizes a Likert-type response format, ranging from $1=$ completely dissatisfied to $7=$ totally satisfied.[46] The scale showed good reliability, possessing Cronbach's $\alpha$ values between 0.77 and 0.90 in the validation studies, while the Cronbach's $\alpha$ values for our study ranged between 0.84 and 0.92 .

The perception of physical and mental health was measured by the Portuguese version of the Medical Outcomes Study, 36-item short form (MOS SF-36).[23,47] This scale has 36 items which evaluate four dimensions of physical health and four dimensions of mental health. The four dimensions evaluated for physical health are physical function, performance limitations due to physical health problems, bodily pain and general health perception. Concerning mental health, the scale's dimensions evaluate limitations in performance due to mental health problems, emotional performance, social function and vitality.

The range of responses can be Likert-type, yes and no, or three-leveled, but the answers must be listed utilizing values ranging from 0 to 100 , with higher scores indicating a more favorable state of health.[25] The Cronbach's $\alpha$ values were between 0.78 and 0.93 in the validation tests of the original scale,[48] and ranged from 0.60 to 0.87 in the version validated for the Portuguese population.[47] In 
this study the Cronbach's $\alpha$ values were between 0.77 and 0.91 .

For the measurement of happiness we used the Covilhã Happiness Questionnaire (CHQ), which was developed by Pereira et al.[49] The scale consists of 41 items, divided into five dimensions: positive emotions, rewarding social interactions, self-care, participation in meaningful activities and engagement with the socioeconomic structure. Responses to the CHQ were obtained using a Likert-type scale ranging from $1=$ strongly disagree to $5=$ strongly agree, and allow for the assessment of the measurement of overall happiness as well as for each of its dimensions. The Cronbach's $\alpha$ coefficient values ranged from 0.63 to 0.90 in the scale's validation studies and were between 0.60 and 0.84 in this investigation.

For the evaluation of subjective well-being, we used the short version of the Portuguese scale of positive and negative affect - PANAS-VRP, which was validated for the Portuguese population by Galinha et al.[50,51] This scale has 10 items that assess positive and negative affect, trait or state as possible responses. In this study, participants were given the following guideline regarding their responses: 'Indicate to what extent, in general, you feel each of these emotions.' The possible answers utilized a Likert scale, ranging from 1 = nothing or very little to $5=$ extremely. In the scale's validation studies, the Cronbach's $\alpha$ values were found to range from 0.86 to 0.89 for positive affect and negative affect, respectively.[52] In this study the Cronbach's $\alpha$ values were 0.88 for positive affect and 0.84 for negative affect.

Self-esteem was measured using the Portuguese version of the Rosenberg Self-Esteem Scale.[53] This scale has 10 items arranged in a Likert-type response format, ranging from 1 = strongly disagree to $4=$ strongly agree, with five of the items being positively orientated and the other five being negatively orientated. The values for the Cronbach's $\alpha$ ranged between 0.77 and 0.88 in the validation studies of the original scale. For the validation of the scale used in studies concerning the Portuguese population, the Cronbach's $\alpha$ value was 0.86 , while in this investigation it was 0.88 , indicating the excellent reliability of the measure.

\subsection{Statistical analysis}

Data analysis was performed using SPSS version 22. Health variables, happiness, subjective well-being and self-esteem were converted into binary measures, using the theoretical median values as references. Values obtained below the theoretical median indicate absence, and values higher than the median indicate presence of the variables. According to the interpretation suggested by the scale's author, the job satisfaction variable was divided into three levels: dissatisfaction, indifference and satisfaction.

For the purposes of logistic regression analysis, the principles of multicollinearity and the proportion of the sample size of the smallest group in the number of predictor variables were observed.[54] Additionally, we considered the value of Hosmer and Lemeshow for each analysis, establishing a significance level of $p=0.05$.

\section{Results}

The results of job satisfaction indicated that the majority of participants reported high satisfaction rates with colleagues (60.8\% satisfied, $22.6 \%$ indifferent, $16.5 \%$ dissatisfied), the nature of their work (61.1\% satisfied, $22.5 \%$ indifferent, 16.4\% dissatisfied) and leadership (55.8\% satisfied, $22.8 \%$ indifferent, $21.3 \%$ dissatisfied). A plurality of respondents reported dissatisfaction concerning their salary $(31.6 \%$ satisfied, $19.2 \%$ indifferent, $49.2 \%$ dissatisfied) and promotions (26.7\% satisfied, $29.2 \%$ indifferent, $44.2 \%$ dissatisfied). Regarding happiness, subjective wellbeing, self-esteem and health, most respondents reported levels above the theoretical median value (see Table 2).

The results showed that job satisfaction was strongly correlated with happiness, $r=0.529, p=0.01$ and the emotional dimension of health, $r=0.401, p=0.01$; and moderately correlated with positive affect, $r=0.344$, $p=0.01$, with self-esteem, $r=0.325, p=0.01$ and with negative affect, $r=-0.259, p=0.01$. We also observed that job satisfaction with was weakly correlated with the physical dimension of health, $r=0.219, p=0.01$. In addition, linear regression analysis showed that happiness, health, self-esteem and well-being exert moderate predictive effects in relation to job satisfaction (see Table 2). It is noted that for the interpretation of these results we used the reference values proposed by Cohen, due to their suitability for the field of social sciences. These values suggest that scores between 0.10 and 0.23 indicate weak correlation; between 0.24 and 0.36 indicate moderate correlation; and 0.37 and above are indicative of strong correlation.[55]

With regards to health, workers satisfied with the nature of their jobs were more likely to report satisfactory physical performance than disgruntled employees, reporting an odds ratio $(O R)$ of $3.68,95 \%$ confidence interval $(\mathrm{CI})$ [1.64, 8.25]. Moreover, workers indicating higher levels of satisfaction with the nature of their jobs were more likely to indicate adequate levels of vitality, reporting $O R$ of $2.40,95 \%$ CI $[1.48,3.89]$. Additionally, workers satisfied with their employment conditions were more likely to report favorable emotional performance, demonstrating $O R$ of $4.77,95 \%$ CI $[2.40,9.49]$. They were also more likely to have better social functioning, reporting $O R$ of $2.46,95 \%$ CI [1.34, 4.49], and were more likely to demonstrate good levels of mental health, reporting OR of 3.33, $95 \%$ CI $[1.85,5.97]$. Examining the health of individuals who reported satisfaction with their colleagues, we find that they were more likely to report higher levels of vitality, reporting $O R$ of $2.00,95 \%$ CI $[1.22,3.28]$, and were 1.96 , $95 \%$ CI $[1.08,3.52]$ times more likely to show adequate mental health levels. Some characteristics related to the 
Table 2. Results for correlation analyses and linear regression assessing job satisfaction as a predictor of health, happiness, subjective well-being and self-esteem $(N=971)$.

\begin{tabular}{|c|c|c|c|c|c|c|c|}
\hline & 1 & 2 & 3 & 4 & 5 & 6 & 7 \\
\hline 1. Job satisfaction & - & & & & & & \\
\hline 2. Global happiness & $0.528 * *$ & & & & & & \\
\hline 3. Positive affect & $0.344 * *$ & $0.575^{* *}$ & & & & & \\
\hline 4. Negative affect & $-0.259 * *$ & $-0.559 * *$ & $-0.262 * *$ & & & & \\
\hline 5. Self-esteem & $0.325 * *$ & $0.644 * *$ & $0.576^{* *}$ & $-0.577 * *$ & & & \\
\hline 6. Physical health & $0.219 * *$ & $0.447 * *$ & $0.288^{* *}$ & $-0.311^{* *}$ & $0.351^{* *}$ & & \\
\hline 7. Emotional health & $0.401 * *$ & $0.702 * *$ & $0.458 * *$ & $-0.602 * *$ & $0.565^{* *}$ & $0.565^{* *}$ & - \\
\hline$M$ & 4.48 & 3.68 & 3.90 & 1.94 & 3.36 & 82.75 & 71.20 \\
\hline$S D$ & 1.09 & 0.50 & 0.69 & 0.77 & 0.47 & 13.31 & 18.11 \\
\hline Dependent variable & \multicolumn{4}{|c|}{ Predictor } & $F$ & \multicolumn{2}{|c|}{ Adjusted $R^{2}$} \\
\hline Global happiness & \multicolumn{4}{|c|}{ Job satisfaction (nature, salary, colleagues) } & $151.79 * * *$ & \multicolumn{2}{|c|}{$0.32(32 \%)$} \\
\hline Positive affect & \multicolumn{4}{|c|}{ Job satisfaction (nature) } & $281.63 * * *$ & \multicolumn{2}{|c|}{$0.22(22 \%)$} \\
\hline Negative affect & \multicolumn{4}{|c|}{ Job satisfaction (nature, colleagues) } & $54.19 * * *$ & \multicolumn{2}{|c|}{$0.99(9.9 \%)$} \\
\hline Self-esteem & \multicolumn{4}{|c|}{ Job satisfaction (nature, colleagues) } & $82.74 * * *$ & \multicolumn{2}{|c|}{$0.14(44 \%)$} \\
\hline Physical health & \multicolumn{4}{|c|}{ Job satisfaction (nature, colleagues) } & $32.99 * * *$ & \multicolumn{2}{|c|}{$0.06(6.0 \%)$} \\
\hline Emotional health & \multicolumn{4}{|c|}{ Job satisfaction (nature, salary, colleagues) } & $80.74 * * *$ & \multicolumn{2}{|c|}{$0.20(20 \%)$} \\
\hline
\end{tabular}

$* * p<0.01 ; * * p<0.001$.

nature of work, such as autonomy and control over one's activities, can produce positive effects on employee health and well-being.[56] These findings provide further confirmation of the effects of job satisfaction on the maintenance of physical, mental and social health.[57,58]

The results also indicated that the chances of a person reporting happiness were $4.01,95 \%$ CI $[2.07,7.78]$ times greater when the respondent assessed the nature of their work positively. In addition, sample members were $3.17,95 \%$ CI $[1.61,6.26]$ times as likely to show happiness when they indicated satisfaction with their colleagues. Regarding the dimensions of happiness, having a favorable assessment of the nature of one's work was associated with a 3.88 -fold, $95 \%$ CI $[2.05,7.35]$ increase in the odds of reporting positive emotions. In addition, participants with a favorable assessment of their work were $2.27,95 \% \mathrm{CI}$ $[1.31,3.95]$ times more likely to have greater self-care scores. They were also $3.14,95 \%$ CI $[1.37,7.18]$ times more likely to report significant participation in activities. A positive assessment of satisfaction with one's colleagues was associated with a 2.64 , CI $95 \%$ [1.33, 5.22] times increase in the chances of showing positive emotions, and these sample members were also $2.96,95 \%$ CI $[1.13,7.72]$ times more likely to participate in rewarding social interactions. Sample participants who indicated satisfaction with promotions were $4.33,95 \%$ CI $[1.37,13.62]$ times as likely to report positive emotions, and were $1.90,95 \%$ CI [1.19, 3.01] times more engaged with the prevailing socioeconomic structures. Satisfaction with wage levels increased engagement with socioeconomic structures 3.44 , 95\% CI $[2.29,5.18]$ times. We also found that subjects satisfied with the nature of their work were $5.68,95 \%$ CI [2.74, $11.78]$ times more likely to display positive affect and $63 \%$ less likely $(O R=0.37), 95 \%$ CI $[0.21,0.65]$ to report negative affect. In accordance with the results obtained in this study, other research suggests that the well-being and happiness reported by workers are positively influenced by the nature and complexity of their work,[59] the relationship with their colleagues and opportunities for career advancement.[9,58]

The chances of reporting favorable self-esteem were $2.82,95 \%$ CI $[1.26,6.31]$ times higher among individuals who reported satisfaction with the nature of their work and $2.45,95 \%$ CI $[1.08,5.56]$ times higher among those who reported satisfaction with their colleagues. Studies suggest that a favorable experience at work can foster increased self-esteem, probably because of the opportunity to establish social interactions, develop skills and experience success and recognition.[60] Table 3 presents the significant results $(O R)$, along with the $95 \%$ CI values and the $p$ values.

\section{Discussion and final considerations}

Correlation analysis and linear regression made it possible to identify the existence of a relationship between job satisfaction, health, happiness, well-being and self-esteem, in line with several investigations previously carried out by other authors.[61-64] For many people, work takes on a role of utmost importance, not only by providing financial support but also by contributing to the development of identity and allowing active participation in society,[65,66] so it is expected that an assessment concerning work has an impact on other spheres of life.[67]

The reported results demonstrate the protector effect of job satisfaction on health, happiness, subjective well-being and self-esteem, in addition to reinforcing the importance of maintaining a positive evaluation of one's work. When 
Table 3. Results for the binary logistic regression assessing job satisfaction as a predictor of health, happiness, subjective well-being and self-esteem.

\begin{tabular}{|c|c|c|c|c|c|}
\hline Variable & $n$ & $\%$ & Dimension JS $(O R)$ & $95 \% \mathrm{CI}$ & $p$ \\
\hline \multicolumn{6}{|l|}{ Health } \\
\hline $\mathrm{PF}$ & 942 & 97.0 & - & - & - \\
\hline PPer & 917 & 94.4 & SNW (3.68) & {$[1.64,8.25]$} & $0.002 * *$ \\
\hline PP & 835 & 86.0 & - & - & - \\
\hline $\mathrm{GHe}$ & 868 & 89.4 & - & - & - \\
\hline EP & 890 & 91.7 & SNW (4.77) & {$[2.40,9.49]$} & $<0.001 * * *$ \\
\hline SF & 870 & 89.6 & SNW (2.46) & {$[1.34,4.49]$} & $0.003 * *$ \\
\hline \multirow[t]{2}{*}{ VT } & 777 & 80.0 & $\mathrm{SC}(2.00)$ & {$[1.22,3.28]$} & $0.006 * *$ \\
\hline & & & SNW (2.40) & {$[1.48,3.89]$} & $<0.001 * * *$ \\
\hline \multirow[t]{2}{*}{$\mathrm{MH}$} & 925 & 87.3 & SC (1.96) & {$[1.08,3.52]$} & $0.025^{* *}$ \\
\hline & & & SNW (3.33) & {$[1.85,5.97]$} & $<0.001 * * *$ \\
\hline \multicolumn{6}{|l|}{ Happiness } \\
\hline \multirow[t]{2}{*}{$\mathrm{GHa}$} & 883 & 90.9 & $\mathrm{SC}(3.17)$ & {$[1.61,6.26]$} & $0.001 * *$ \\
\hline & & & SNW (4.01) & {$[2.07,7.78]$} & $<0.001^{* * *}$ \\
\hline \multirow[t]{3}{*}{$\mathrm{PE}$} & 879 & 90.5 & $\mathrm{SC}(2.64)$ & {$[1.33,5.22]$} & $0.005 * *$ \\
\hline & & & SNW (3.88) & {$[2.05,7.35]$} & $<0.001 * * *$ \\
\hline & & & SP $(4.33)$ & {$[1.37,13.62]$} & $0.012 *$ \\
\hline SGI & 930 & 95.8 & $\mathrm{SC}(2.96)$ & {$[1.13,7.72]$} & $0.026^{*}$ \\
\hline SCA & 840 & 86.5 & SNW (2.27) & {$[1.31,3.95]$} & $0.004 * *$ \\
\hline PMA & 919 & 94.6 & SNW (3.14) & {$[1.37,7.18]$} & $0.007 * *$ \\
\hline \multirow[t]{2}{*}{ SSE } & 295 & 30.4 & SS (3.44) & {$[2.29,5.18]$} & $<0.001 * * *$ \\
\hline & & & SP (1.90) & {$[1.19,3.01]$} & $0.006 * *$ \\
\hline \multicolumn{6}{|c|}{ Subjective well-being } \\
\hline PA & 896 & 92.3 & SNW (5.68) & {$[2.74,11.78]$} & $<0.001 * * *$ \\
\hline NA & 121 & 12.5 & SNW (0.37) & {$[0.21,0.65]$} & $0.01 * *$ \\
\hline \multirow[t]{2}{*}{ Self-esteem } & 911 & 93.8 & $\mathrm{SC}(2.45)$ & {$[1.08,5.56]$} & $0.03^{*}$ \\
\hline & & & SNW (2.82) & {$[1.26,6.31]$} & $0.01 * *$ \\
\hline
\end{tabular}

$* p<0.05 ; * * p<0.01 ; * * *<0.001$.

Note: $\mathrm{CI}=$ confidence interval; $\mathrm{EP}=$ emotional performance; $\mathrm{GHa}=$ global happiness; $\mathrm{GHe}=$ general health; JS = job satisfaction; $\mathrm{MH}=$ mental health; $\mathrm{NA}=$ negative affect; $\mathrm{OR}=$ odds ratio; $\mathrm{PA}=$ positive affect; $\mathrm{PE}=$ positive emotions; $\mathrm{PF}=$ physical function; $\mathrm{PMA}=$ participation in meaningful activities; $\mathrm{PP}=$ physical pain; $\mathrm{PPer}=$ physical performance; $\mathrm{SC}=$ satisfaction with colleagues; $\mathrm{SCA}=$ self-care; $\mathrm{SF}=$ social function; $\mathrm{SGI}=$ social gratifying interaction; $\mathrm{SNW}=$ satisfaction with nature of work;

$\mathrm{SP}=$ satisfaction with promotions; $\mathrm{SS}=$ satisfaction with salary; $\mathrm{SSE}=$ socioeconomic structure engagement; VT $=$ vitality.

comparing individuals who show dissatisfaction with their work with those who demonstrate satisfaction, the current study found that those who evaluated their job in a positive manner are more likely to be healthy, with the most prominent effects evident in the dimensions of emotional performance and mental health. Satisfaction with the nature of one's work and with one's colleagues positively influenced physical and mental performance, decreased the chances of individuals feeling the need to reduce their amount of work and decreased workers' difficulties in performing their duties. High reported job satisfaction also increased the odds of reporting good energy levels, increased the quality and quantity of social interactions, and provided workers with additional protection from anxiety, depression and a loss of emotional and behavioral control.

Work plays a key role in psychological protection,[68] and satisfaction with work-related activities and social interactions can help in the recovery of people with mental illness.[69] Furthermore, maintaining workers' health promotes job satisfaction and minimizes costs associated with health insurance and employee absenteeism.[70]
The study found that individuals who revealed more optimism, greater life satisfaction and a higher ability to deal with adverse situations tended to express increased satisfaction with the nature of their employment activities, with the number of promotions received and with the relationships that they have with their colleagues. Participants who were more likely to demonstrate self-care and involvement in meaningful activities, whether social, cultural or political, were also more satisfied with the variety and interest generated by the tasks developed.

Moreover, the study found that contentment in relationships with coworkers increased the chances of social integration. The results also show that satisfaction with salary and promotion opportunities increased one's chances of reporting satisfaction with regard to politics, the economy and justice.

There is evidence that happier people have more favorable work-related results and that those who regularly experience positive emotions and pleasant moods feel safer in the pursuit of their goals, are more likely to effectively confront challenges and are more prone to make 
assertive decisions.[71] Studies also indicate that organizational commitment is more frequent among people who are happy and experience a greater frequency of positive affect.[72]

Finally, individuals who felt more respect and value demonstrated greater satisfaction with work-related activities and relationships with their coworkers. Studies indicate that individuals with high self-esteem are less indecisive concerning their careers.[73] Individuals demonstrating high levels of self-esteem also tend to view their careers as successful more often than those with low self-esteem,[74] and they also report higher wages, greater work-related engagement and better job satisfaction.[75]

As a practical implication, the results suggest that the effects of personnel management policies that emphasize job satisfaction can potentially generate improvements in the levels of health, happiness, subjective well-being and workers' self-esteem, all of which are factors that can improve organizational performance.

This study was not without its limitations. The convenience sample was composed solely of Portuguese speakers, which compromises the ability to generalize the obtained results on an international scale. The considered sample presented also highly educated professional workers and a disproportionate of high number of "job satisfied' participants. Moreover, this cross-sectional study focused on various constructs of self-assessment that tend to change over time. Thus, it is important that longitudinal studies with the aim of observing changes and further developing the evaluated constructs should be conducted in the future.

There are many prior studies that have assessed the influence of job satisfaction on maintaining health, happiness, well-being and self-esteem. However, this research offers a unique approach, and seeks to highlight that individuals satisfied with their work tend to be happier, healthier and report more favorable levels of self-esteem.

\section{Disclosure statement}

No potential conflict of interest was reported by the authors.

\section{References}

[1] Stoilkovska BB, Žileska Pančovska V, Mijoski G. Relationship of safety climate perceptions and job satisfaction among employees in the construction industry: the moderating role of age. Int J Occup Saf Ergon. 2015;21(4):440-447. doi:10.1080/10803548.2015.1096059.

[2] Jernigan IE, Beggs JM, Kohut GF. Dimensions of work satisfaction as predictors of commitment type. J Manag Psychol. 2002;17(7):564-579. doi:10.1108/026839402104 44030.

[3] Sánchez-Sellero MC, Sánchez-Sellero P, Cruz-Gonzáles $\mathrm{MM}$, et al. Características organizacionales de la satisfacción laboral en España [Organizational characteristics of job satisfaction in Spain]. Rev Adm Empres. 2014;54(5):537547. doi:10.1590/S0034-759020140507.
[4] Folami LB, Asare K, Kwesiga E, et al. The impact of job satisfaction and organizational context variables on organizational commitment. Int J Bus Public Adm. 2014;11(2): $1-19$.

[5] Wegge J, Schmidt K-H, Parkes C, et al. Taking a sickie: job satisfaction and job involvement as interactive predictors of absenteeism in a public organization. J Occup Organ Psychol. 2007;80(1):77-89. doi:10.1348/096317906X99371.

[6] Zopiatis A, Constanti P, Theocharous AL. Job involvement, commitment, satisfaction and turnover: evidence from hotel employees in Cyprus. Tour Manag. 2014;41:129-140. doi:10.1016/j.tourman.2013.09.013.

[7] Jorge AT, Gina DR, Rocha LE, et al. Fatores de risco associados à satisfação no trabalho em trabalhadores de nutrição hospitalar [Risk factors associated with job satisfaction in hospital nutrition workers]. Saúde, Ética \& Justiça. 2008;13(2):95-103. doi:10.11606/issn.2317-2770. v13i2p95-103.

[8] Martinez MC, Paraguay AIBB. Satisfação e saúde no trabalho: aspectos conceituais e metodológicos [Satisfaction and health at work - conceptual and methodological aspects]. Cad Psicol Soc e do Trab. 2003;6:59-78. doi:10.11606/issn.1981-0490.v6i0p59-78.

[9] Bowling NA, Hendricks EA, Wagner SH. Positive and negative affectivity and facet satisfaction: a meta-analysis. J Bus Psychol. 2008;23:115-125. doi:10.1007/s10869-0089082-0.

[10] Bowling NA, Eschleman KJ, Wang Q. A meta-analytic examination of the relationship between job satisfaction and subjective well-being. J Occup Organ Psychol. 2010;83(4):915-934. doi:10.1348/096317909X478557.

[11] Č́ábelková I, Abrhám J, Strielkowski W. Factors influencing job satisfaction in post-transition economies: the case of the Czech Republic. Int J Occup Saf Ergon. 2015;21(4):448456. doi:10.1080/10803548.2015.1073007.

[12] Templer KJ. Five-factor model of personality and job satisfaction: the importance of agreeableness in a tight and collectivistic Asian society. Appl Psychol. 2012;61(1):114 129. doi:10.1111/j.1464-0597.2011.00459.x.

[13] Orsila R, Luukkaala T, Manka M-L, et al. A new approach to measuring work-related well-being. Int J Occup Saf Ergon. 2011;17(4):341-359. doi:10.1080/10803548.2011. 11076900

[14] Fernandes MN, Junior SG, de Oliveira ÁF. Saúde organizacional: uma proposta de modelo de análise [Organizational health: an analysis model proposal]. Rev Psicol Organ e Trab. 2011;11(1):54-65.

[15] Paschoal T, Tamayo Á. Validação da escala de estresse no trabalho [Work stress scale validation]. Estud Psicol. 2004;9(1):45-52. doi:10.1590/S1413-294X2004000100 006.

[16] Martins M, Santos G. Adaptação e validação de construto da escala de satisfação no trabalho [Adaptation and validation of the work satisfaction scale]. Psico-USF. 2006;11(2):195205. doi:10.1590/S1413-82712006000200008.

[17] Locke EA. The nature and causes of job satisfaction. In: Dunnette MD, editor. Handbook of industrial and organizational psychology. Chicago (IL): Rand McNally; 1976. p. 1297-1349.

[18] Carlotto MS, Câmara SG. Propriedades psicométricas do Questionário de Satisfação no Trabalho (S20/23) [Psychometric properties of the work satisfaction questionnaire (S20/23)]. Psico-USF. 2008;13(2):203-210.

[19] Tamayo A. Propriedades axiologicas e satisfação no trabalho [Axiological properties and job satisfaction]. Rev Adm. 2000;35(2):37-47. 
[20] Cavalhieri KE. Processo de adaptação de uma escala de satisfação no trabalho ao contexto das emrpesas juniores: resultados preliminares [Adaptation process of a work satisfaction scale to the junior companies context: preliminary results]. Barbarói. 2013;39:164-191.

[21] Siqueira MMM. Satisfação no trabalho [Job satisfaction]. In: Siqueira MMM, editor. Medidas do comportamento organizacional: ferramentas de diagnóstico e de gestão [Organizational behavior measures: diagnosis and management tools]. Porto Alegre: Artmed; 2008. p. 257-266.

[22] World Health Organization. Our planet, our health, our future [Internet]. 2012 [cited 2016 Feb 12]. Available from: http://www.who.int/globalchange/publications/reports/heal th_rioconventions.pdf?ua $=1$.

[23] Ferreira PL. Criação da versão portuguesa do MOS SF36. Parte I - Adaptação cultural e linguística [Creation of the Portuguese version of MOS SF-36. Part I - cultural and linguistic adaptation]. Acta Med Port. 2000; 13:55-66.

[24] Weare K. Promoting mental, emotional and social health London: Routledge; 2000.

[25] Ware JE, Gandek B, Group IP. The SF-36 health survey: development and Use in mental health research and the IQOLA project. Int J Ment Health. 1994;23(2):49-73. doi:10.1080/00207411.1994.11449283.

[26] Diener E, Ryan K. Subjective well-being: a general overview. South African J Psychol. 2009;39(4):391-406. doi: $10.1177 / 008124630903900402$

[27] Paschoal T, Tamayo A. Construção e Validação da escala de bem-estar no trabalho [Construction and validation of the well-being at work scale]. Avaliação Psicológica. 2008;7(1):11-22.

[28] Diener E, Suh EM, Lucas RE, et al. Subjective well-being: three decades of progress. Psychol Bull. 1999;125(2):276302. doi:10.1037/0033-2909.125.2.276.

[29] Hills P, Argyle M. Emotional stability as a major dimension of happiness. Pers Individ Dif. 2001;31(8):1357-1364. doi:10.1016/S0191-8869(00)00229-4.

[30] Veenhoven R. Sociological theories of subjective wellbeing. In: Eid M, Larsen RJ, editors. The science of subjective well-being. New York (NY): The Guilford Press; 2008. p. $44-61$.

[31] Zeigler-Hill V. The importance of self-esteem. In: ZeiglerHill V, editor. Self-esteem. London: Psychology Press; 2013. p. 1-20.

[32] Robinson JP, Shaver PR, Wrightsman LS. Measures of personality and social psychological attitudes. San Diego (CA): Academic Press; 1991.

[33] Kernis MH. Target article: toward a conceptualization of optimal self-esteem. Psychol Inq. 2003;14(1):1-26. doi:10.1207/S15327965PLI1401_01.

[34] Schultheisz TSDV, Aprile MR. Autoestima, conceitos correlatos e avaliação [Self-esteem, related concepts and assessment]. Rev Equilíbrio Corpor e Saúde. 2013;5(1):3648.

[35] Martín-Albo J, Núñez JL, Navarro JG, et al. The Rosenberg self-esteem scale: translation and validation in university students. Span J Psychol. 2007;10(2):458-467. doi:10.1017/S1138741600006727.

[36] Orth U, Robins RW. The development of self-esteem. Curr Dir Psychol Sci. 2014;23(5):381-387. doi:10.1177/0963721 414547414

[37] Bowling NA, Eschleman KJ, Wang Q, et al. A meta-analysis of the predictors and consequences of organization-based self-esteem. J Occup Organ Psychol. 2010;83(3):601-626. doi:10.1348/096317909X454382.
[38] Warr PB. Work, happiness, and unhappiness. Mahwah (NJ): Erlbaum; 2011

[39] Georgellis Y, Lange T, Tabvuma V. The impact of life events on job satisfaction. J Vocat Behav. 2012;80(2):464 473. doi:10.1016/j.jvb.2011.12.005.

[40] Sanz-Vergel AI, Rodríguez-Muñoz A, Nielsen K. The thin line between work and home: the spillover and crossover of daily conflicts. J Occup Organ Psychol. 2015;88(1):1-18. doi:10.1111/joop. 12075 .

[41] Peng J, Li D, Zhang Z, et al. How can core selfevaluations influence job burnout? The key roles of organizational commitment and job satisfaction. J Health Psychol. 2016;21(1):50-59. doi:10.1177/1359105314521478.

[42] Kuster F, Orth U, Meier LL. High self-esteem prospectively predicts better work conditions and outcomes. Soc Psychol Personal Sci. 2013;4(6):668-675. doi:10.1177/1948550613 479806.

[43] Zhang J, Wu Q, Miao D, et al. The impact of core self-evaluations on job satisfaction: the mediator role of career commitment. Soc Indic Res. 2013;116(3):809-822. doi:10.1007/s11205-013-0328-5.

[44] de Vaus DA. Surveys in social research. 6th ed. Abingdon: Routledge; 2014.

[45] Ramsey SR, Thompson KL, McKenzie M, et al. Psychological research in the internet age: the quality of web-based data. Comput Human Behav. 2016;58:354-360. doi:10.1016/j.chb.2015.12.049.

[46] Siqueira MMM. Satisfação no trabalho [Job satisfaction]. In: Siqueira MMM, editor. Medidas do comportamento organizacional [Organizational behavior measures]. Porto Alegre: Artmed; 2008. p. 257-266.

[47] Ferreira PL. Criação da versão portuguesa do MOS SF-36. Parte II - testes de validação [Creation of the Portuguese version of MOS SF-36. Part II - validation tests]. Acta Med Port. 2000;13:119-127.

[48] McHorney CA, Ware JE, Lu JFR, et al. The MOS 36ltem short-form health survey (SF-36): III. tests of data quality, scaling assumptions, and reliability across diverse patient groups. Med Care. 1994;32(1):40-66. doi:10.1097/ 00005650-199401000-00004.

[49] Pereira H, Monteiro S, Esgalhado G, et al. Measuring happiness in Portuguese adults: validation of the CHQ - Covilha happiness questionnaire. J Psychol Psychother. 2015;05(168):1-7.

[50] Galinha IC, Pereira CR, Esteves F. Versão reduzida da escala portuguesa de afeto positivo e negativo - PANASVRP: Análise fatorial confirmatória e invariância temporal [Portuguese scale of positive and negative affect - PANASVRP reduced version: Confirmatory factor analysis and temporal invariance]. Rev Psicol. 2014;28(1):53-65.

[51] Galinha IC, Pais-Ribeiro JL. Contribuição para o estudo da versão portuguesa da positive and negative affect schedule (PANAS): I - abordagem teórica ao conceito de afecto [Contribution to the study of the Portuguese version of the positive and negative Affect Schedule (PANAS): I-theoretical approach to the affection concept]. Análise Psicológica. 2005;2(23):209-218.

[52] Galinha IC, Pais-Ribeiro JL. Contribuição para o estudo da versão portuguesa da Positive and Negative Affect Schedule (PANAS): II - Estudo psicométrico [Contribution to the study of the Portuguese version of the Positive and Negative Affect Schedule (PANAS): II - psychometric study]. Análise Psicológica. 2005;2(23):219-227.

[53] Santos PJ, Maia J. Análise factorial confirmatória e validação preliminar de uma versão portuguesa da escala de auto-estima de Rosenberg [Confirmatory factor analysis and 
preliminary validation of a Portuguese version of the selfesteem Rosenberg scale]. Psicologia: Teoria, Investigaçäo e Prática. 2003;2:253-268.

[54] Leech NL, Barrett KC, Morgan GA. IBM SPSS for intermediate statistics: use and interpretation. 5th ed. New York (NY): Routledge; 2015.

[55] Cohen J. Statistical power analysis for the behavioral sciences. 2nd ed. Hillsdale (NJ): Erlbaum; 1988.

[56] Stephan U, Roesler U. Health of entrepreneurs versus employees in a national representative sample. J Occup Organ Psychol. 2010;83(3):717-738. doi:10.1348/096317 909X472067.

[57] Yuan L, Tan X, Huang C, et al. Mediating effect of job satisfaction on the relationship between emotional intelligence and perceived general health. Soc Behav Pers. 2014;42(7):1057-1067. doi:10.2224/sbp.2014.42.7. 1057.

[58] Filiz Z. An analysis of the levels of job satisfaction and life satisfaction of the academic staff. Soc Indic Res. 2014;116(3):793-808. doi:10.1007/s11205-013-0319-6.

[59] Chung-Yan GA. The nonlinear effects of job complexity and autonomy on job satisfaction, turnover, and psychological well-being. J Occup Health Psychol. 2010;15(3):237-251. doi:10.1037/a0019823.

[60] Trzesniewski KH, Donnellan MB, Robins RW. Development of self-esteem. In: Zeigler-Hill V, editor. Self-esteem. London: Psychology Press; 2013. p. 60-79.

[61] Dabke D. Can life satisfaction be predicted by emotional intelligence, job satisfaction and personality type? aWEshkar. 2014;17(1):22-33.

[62] Bruk-Lee V, Khoury HA, Nixon AE, et al. Replicating and extending past personality/job satisfaction meta-analyses. Hum Perform. 2009;22(2):156-189. doi:10.1080/08959 280902743709

[63] Dockery AM. The happiness of young Australians: empirical evidence on the role of labour market experience. Econ Rec. 2005;81(255):322-335. doi:10.1111/j.1475-4932.2005. 00272.x.

[64] Chiron B, Michinov E, Olivier-Chiron E, et al. Job satisfaction, life satisfaction and burnout in French anaesthetists. J Health Psychol. 2010;15(6):948-958. doi: $10.1177 / 1359105309360072$.

[65] Borges LDO, Tamayo Á. A estrutura cognitiva do significado do trabalho [The cognitive structure of the work meaning]. rPOT. 2001;1(2):11-44.

[66] Morin E, Tonelli MJ, Pliopas ALV. O trabalho e seus sentidos [Work and its meanings]. Psicol Soc. 2007;19(spe):4756. doi:10.1590/S0102-71822007000400008.

[67] Russell JEA. Promoting subjective well-being at work. J Career Assess [Internet]. 2008 Feb 1 [cited 2014 Nov 10];16(1):117-31. Available from: http://jca.sagepub.com/ cgi/doi/10.1177/1069072707308142.

[68] Blustein DL. The role of work in psychological health and well-being: a conceptual, historical, and public policy perspective. Am Psychol. 2008;63(4):228-240. doi:10.1037/ 0003-066X.63.4.228.

[69] Auerbach ES, Richardson P. The long-term work experiences of persons with severe and persistent mental illness. Psychiatr Rehabil J. 2005;28(3):267-273. doi:10.2975/28. 2005.267.273

[70] Parks KM, Steelman LA. Organizational wellness programs: a meta-analysis. J Occup Health Psychol. 2008;13(1) 58-68. doi:10.1037/1076-8998.13.1.58.

[71] Boehm JK, Lyubomirsky S. Does happiness promote career success? J Career Assess. 2008;16(1):101-116. doi:10.1177/1069072707308140.

[72] Mignonac K, Herrbach O. Linking work events, affective states, and attitudes: an empirical study of managers' emotions. J Bus Psychol. 2004;19(2):221-240. doi:10.1007/ s10869-004-0549-3.

[73] Bacanli F. Personality characteristics as predictors of personal indecisiveness. J Career Dev. 2006;32(4):320-332. doi:10.1177/0894845305282941.

[74] Judge TA, Hurst C. How the rich (and happy) get richer (and happier): relationship of core self-evaluations to trajectories in attaining work success. J Appl Psychol. 2008;93(4):849 863. doi:10.1037/0021-9010.93.4.849.

[75] Salmela-Aro K, Nurmi JE. Self-esteem during university studies predicts career characteristics 10 years later. J Vocat Behav. 2007;70(3):463-477. doi:10.1016/j.jvb.2007.01.006. 